\title{
UPAYA MEMERANGI TINDAKAN PENCUCIAN UANG (MONEY LAUNDRING) DI INDONESIA
}

\author{
Oleh:
}

\author{
Edi Waluyo
}

Fakultas Hukum Universitas Jenderal Soediram Purwokerto

\begin{abstract}
The problems of prevention of money loundry is not easy and simple problem, world power Problems of prevention of wash of money is not easy and simple problem, even for international. At this millennium, the phenomenon fight money laundry is improving which in international scale by various states, and in domestic level. The international effort is not only emphasizing to the making of law and regulation that instructed to fight crimes organized especially trafficking, drug organized but also other various crime. Indonesia effort to fight in money laundry by gradual through two policy of law, that is with prevention approach in banking law such as Knowing Your Customer Principle and policy of Criminal law as repressive approach in money laundry as arranged in Law No. 15 Year 2002 jo Law No. 25 Year 2003.
\end{abstract}

Kata Kunci : money laundering, Knowing Your Customer Principle.

\section{A. Pendahuluan}

Pada saat ini dunia internasional makin gencar melakukan upaya-upaya memerangi praktik pencucian uang (money laundering), baik melalui kerjasama bilateral diantara dua negara maupun forum-forum kerjasama internasional seperti Financial Action Task Force 1989 (FATF) beranggotakan 29 negara maju (Eropa, Amerika Utara dan Asia) yang menekankan pentingnya pemberantasan pencucian uang. Dalam rekomendasinya FATF menyatakan bahwa setiap negara harus memiliki rezim hukum anti pencucian uang.

Pendekatan yang dilakukan oleh FATF dalam memerangi praktik pencucian uang adalah bersifat memberikan hukuman (punitive approach), artinya terhadap negara-negara yang dianggap tidak kooperatif dalam memerangi praktik pencucian uang akan dikenakan tindakan balasan (counter measure) oleh negara-megara anggota FATF dalam ben-tuk hambatan terhadap transaksi perbankan seperti transfer, L/C, pinjaman luar negeri, larangan membuka kantor cabang bank di luar negeri atau seluruh transaksi dari negara tersebut dianggap sebagai transaksi yang mencurigakan (suspicious transaction). ${ }^{1}$

Sehubungan dengan gerakan penanggulangan kejahatan pencucian uang sebagaimana dimaksud, pada bulan Juni 2001 bersama 15 negara lainnya - seperti antara lain Filipina dan Myanmar, - oleh FATF Indonesia dimasukkan dalam daftar Non-Cooprative Countries and Territories (NCCT). Dasar dari dimasuk-kannya Indonesia dalam blacklist FATF adalah:

1. Pada saat itu Indonesia belum memiliki undang-undang anti pencucian uang. Dalam hal ini Indonesia dianggap tidak konsekuen karena pada tahun 1997 telah meratifikasi United Nation Convention Against Illisit Traffic Narcotic Drugs and Psychotropic Substances 1988, sehingga seharusnya sejak saat itu segera melakukan upaya pemberantasan pencucian uang; ${ }^{2}$

2. Indonesia ditengarai sebagai surga bagi pencucian uang, karena Indonesia menganut regim devisa bebas, kerahasiaan bank masih sangat ketat, tingkat korupsi yang selalu menduduki peringkat tinggi serta kejahatan narkotika juga sangat marak,

Yenti Garnasih, Pencucian Uang dan Permasalahan Penegakannya di Indonesia, Newsletter No. 58/September/2004, hlm. 2

2 Ibid. 
ditambah lagi kebutuhan dana dari luar negeri dalam jumlah yang cukup besar untuk keperluan pembangunan, membuat Indonesia sebagai tempat yang menarik bagi para pelaku pencuci uang. ${ }^{3}$

Sejalan dengan laporan dari FATF, da-lam laporan Departemen Luar Negeri Amerika Serikat tahun 2000, Indonesia bersama empat puluh satu negara lainnya dikategorikan sebagai major money laundering countries, atas dasar beberapa alasan yaitu: selama itu orang yang menyimpan uang di bank tidak pernah ditanyakan asal-usulnya; Indonesia menganut sistem devisa bebas dengan perekonomian terbuka, sehingga siapa saja boleh memiliki devisa, menggunakan untuk kegiatan apa saja dan tidak ada kewajiban untuk menjualnya kepada negara atau bank sentral; ketentuan rahasia bank di Indonesia cukup ketat dengan pengecualian yang bersifat terbatas; terdapat kondisi yang me-nunjang yaitu adanya saving investment gap, yang mengakibatkan Indonesia memerlukan banyak pinjaman dana dari luar negeri dan dengan adanya tindakan keras Amerika Serikat dalam memberantas money laundering di negaranya dan negara tetangganya, terdapat kemungkinan uang hasil tindak pidana penjualan narkotika lari ke Indonesia untuk dicuci. ${ }^{4}$

Masuknya Indonesia dalam balcklist FATF jelas berdampak negatif bagi Indonesia di mata lembaga keuangan internasional, karena negara-negara maju yang termasuk anggota FATF diminta untuk memberikan perhatian khusus jika melakukan transaksi keuangan dengan orang, perusahaan atau lembaga keuangan dari 15 negara tersebut, dan ada kemungkinan akan dikenakan sanksi dalam bentuk tindakan balasan.

Berdasarkan uraian tersebut diatas, penulis tertarik untuk membahas beberapa permasalahan yang muncul sehubungan dengan perihal pencucian uang yaitu alasan praktik pencucian uang perlu diperangi dan upaya

3 Eddhie Trinugroho, Perkembangan Pemberantasan Tindak Pidana Pencucian Uang di Indonesia, Newsletter No. 58/September 2004. hlm. 9

4 Yunus Husein, Keberadaan Undang-undang Money Laundering, Newsletter No. 48/Maret/2002. hlm. 21
Indonesia dalam memerangi praktik pencucian uang.

\section{B. Pembahasan}

1. Pengertian dan sejarah tentang pencucian uang.

Istilah, "pencucian uang" merupakan terjemahan dari "money launderin," yang sebagai sebutan sebenarnya belum lama dipakai. Istilah money laundering telah dikenal sejak tahun 1930 di Amerika Serikat. Pada saat itu tindak pidana ini dilakukan oleh organisasi tindak pidana "mafia" melalui pembelian perusahaan-perusahaan pencucian pakaian (laundry) yang kemudian digunakan oleh organisasi tersebut sebagai tempat pencucian uang yang dihasilkan dari bisnis ilegal seperti perjudian, pelacuran, dan perdagangan minuman keras. Dan sejak itu diterima dan digunakan secara luas di seluruh dunia. ${ }^{5}$

Sedangkan dari segi pengertian, sebagaimana dikatakan oleh Sutan Remy Syahdeini, sebenarnya tidak ada definisi yang universal dan komprehensif mengenai apa yang dimaksud sebagai pencucian uang. Setiap pihak - seperti pihak menuntut, penyidik, kalangan pengusaha, dan negara-negara maju dan negara-negara dunia ketiga - masing-masing mempunyai definisi tersendiri berdasarkan prioritas dan perspektif yang berbeda. ${ }^{6}$

Namun demikian secara sederhana pencucian uang (money laundering) dapat diartikan sebagai :

suatu proses yang dilakukan untuk merubah uang hasil kejahatan, sehingga uang hasil kejahatan tersebut menjadi nampak sebagai hasil kegiatan yang sah karena asal-usulnya sudah disamarkan atau disembunyikan. ${ }^{7}$

Alasan mengapa uang hasil kejahatan harus dicuci lebih dahulu? Karena kejahatan yang menghasilkan uang dalam jumlah yang sangat besar, apabila digunakan secara lang-sung, akan mengundang kecurigaan - terutama aparat penegak hukum. Untuk itulah pelaku

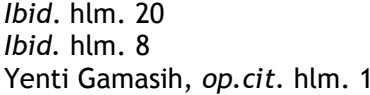


kejahatan melakukan tindakan menyamarkan atau menyembunyikan hasil kejahatan agar tidak terdeteksi oleh aparat, sehingga hasil kejahatan tersebut dapat digunakan secara aman, seakan-akan berasal dari kegiatan yang sah.

Proses pencucian uang tersebut dilakukan melalui kegiatan-kegiatan legal, an-tara lain dengan memanfaatkan lembaga-lembaga keuangan khususnya perbankan, atau usaha real estate, money changer dan usaha lainnya. Pada dasarnya kegiatan tersebut terdiri dari tiga langkah yang masing-masing berdiri sendiri, tetapi seringkali dilakukan bersama-sama yaitu placement, layering dan integration. ${ }^{8}$

Placement (penempatan), yaitu upaya menempatkan uang yang dihasilkan dari suatu aktivitas kejahatan. Dalam hal ini terdapat pergerakan fisik dari uang tunai melalui penyelundupan uang tunai dari suatu negara ke negara lain; atau menggabungkan uang yang berasal dari kejahatan dengan uang yang diperoleh dari hasil kegiatan yang sah; ataupun dengan melakukan penempatan uang giral ke dalam sistem perbankan seperti deposito bank, cek atau melalui real estate atau saham-saham atau juga mengkonversikan ke dalam mata uang lainnya atau transfer uang ke dalam valuta asing.

Layering (pelapisan), yaitu memisahkan uang hasil kejahatan dari sumbernya melalui beberapa tahapan transaksi keuangan. Dalam hal ini terdapat proses pemindahan dana hasil plecement dari suatu tempat atau lokasi tertentu ke tempat lain melalui serangkaian transaksi yang didesain untuk menyamarkan/ mengelabui sumber dana haram tersebut, sehingga menutupi identitas pemilik yang sebenarnya maupun sumber uang haram tersebut. Prasarana yang digunakan dapat berupa transfer berbagai rekening bank atas nama nasabah yang tidak saling mengenal satu

Elaborasi dari Eddhie Trinugroho, Perkembangan Pemberantasan Tindak Pidana Pencucian Uang di Indonesia, Newsletter No. 58/September 2004. hlm. 7 8 dan Muhammad Aulia Gislir, Aspek Hukum Praktek Money Laundering Melalui Sarana Perbankan, Newsletter No. 39/X/Desember/1999. hlm. 13. sama lain antar bank antar negara, atau berupa persahaan gadungan yang disengaja dibentuk dan beroperasi di manca negara.

Integration (penggabungan), yaitu upaya menetapkan suatu landasan sebagai "legitimate explanation" bagi hasil kejahatan. Dalam hal ini, uang haram yang telah dicuci melalui placement maupun layering dialihkan ke dalam kegiatan-kegiatan resmi sesuai dengan aturan hukum sehingga tampak tidak berhubungan sama sekali dengan aktivitas kejahatan sebelumnya yang menjadi sumber dari uang yang dicuci. Pada tahap ini uang yang telah dicuci dimasukkan kembali ke dalam bentuk yang sesuai dengan aturan hukum.

Dengan menggunakan metode ter-sebut, uang hasil kejahatan menjadi sulit dilacak karena melalui proses legal, uang yang berasal dari kejahatan telah diputihkan sehingga uang tersebut menjadi seolah-olah berasal dari sumber keuangan yang legal, sehingga pelaku kejahatan dapat bebas dan aman menggunakannya.

Pemikiran untuk menyatakan tindakan pencucian uang sebagai tindakan illegal berawal dari kewalahannya aparat penegak hukum dalam memberantas kejahatan narkotika yang sudah sangat meresahkan secara internasional. Berbagai upaya telah dilakukan untuk menahan meningkatnya kejahatan narkotika, namun dalam kenyataannya kejahatan bukannya menurun tetapi bahkan meningkat. Maka muncullah strategi untuk menanggulangi kejahatan narkotika yang menghasilkan uang sangat besar agar tidak dapat digunakan. Strategi penanggulangan kejahatan narkotika tersebut berupa kriminalisasi tindakan pencucian uang, dengan maksud sebagai sarana untuk mencegah agar pelaku kejahatan narkotika tidak dapat menikmati hasil kejahatannya. Dengan mencegah dan merusak hasil kejahatan, dalam perkembangannya, kriminalisasi pencucian uang kemudian tidak saja digunakan untuk mencegah pelaku kehatan narkotik saja, melainkan juga dari kejahatan lainnya, dengan harapan motivasi melakukan tindakan kejahatanpun akan sirna. 
Dengan demikian pemberantasan pencucian uang dipandang sebagai cara yang paling efektif untuk mencari leader of organized criminal enterprise dan selanjutnya dikatakan bahwa pelaku pencucian uang lebih mudah ditangkap daripada menangkap pelaku kejahatan utamanya (predicate offence). Pada akhirnya strategi tersebut diaktualisasikan dalam upaya internasional mengambil berbagai inisiatif pemberantasannya, antara lain dideklarasikannya United Nation Convention Against Illisit Traffic Narcotic Drugs and Psycho-tropic Substances 1988 (Vienna Convention 1988) yang merupakan tonggak berdirinya International Legal Regime on Money Laundering. Selanjutnya muncul grup-grup antar negara seperti Financial Action Task Force 1989 (FATF) yang beranggotakan 29 negara maju yang menekankan pentingnya pemberantasan pencucian uang.

Dengan semangat dan atas inisiatif PBB dalam menanggulangi kejahatan pencucian uang, maka FATF mengadopsi pendekatan multi-disipliner terhadap masalah pencucian uang dan sekaligus merekomendasikan kebijakan kekuasaan pembuatan hukum, lembaga keuangan dan penegakan hukum. Setelah itu kemudian lahir berbagai badan seperti Caribbean Financial Action Task Forcee 1990, Convention On Laundering, Search, Seizure and confiscation of the Proceed from Crime (Council of Europe) 1990, Counsil Directive on Prevention of the use of the Financial System for thr purpose of Money Laundering (June 1991), Organization of Americas State (OAS 1992), Interpol, Summit of the Americas (1995), serta Asia Pasific Group (APG) dan Egmond Group. Indonesia telah masuk sebagai anggota APG dan Egmond Group 23 Juni 2004. ${ }^{9}$

Penegasan selanjutnya bahwa pencucian uang merupakan masalah internasional yang serius, dinyatakan dalam: ${ }^{10}$

a. Conference of Money Trail: Internasional Money Laundering Trends and Prevention/ Control Policies, yang diseleng-garakan di

9 Yenti Gamasih, op.cit. hlm. 2

10 Ibid, hlm. 2-4
Courmayeur, Italia pada Juni 1994. Dalam konferensi tersebut dinyatakan bahwa prakrik pencucian uang pada umumnya menggunakan sarana lembaga keuangan, maka kejahatan ini sangat membahayakan dan dapat merusak lem-baga keuangan baik lembaga perbankan ataupun nonperbankan.

b. United Nation Congress on The Prevention of Crime and treatment of Offenders, 1885 di Cairo, yang menyatakan ada tujuhbelas jenis kategori kejahatan serius (serious crime) dan pencucian uang menempati urutan pertama.

c. United Nation Convention against Corruption Desember 2003 yang menekankan bahaya pencucian uang dalam kaitannya dengan korupsi di berbagai bidang. Dari tinjauan politik dan keamanan, pencucian uang sangat berbahaya, karena pencucian uang tidak lagi terbatas dari hasil penjualan gelap narkotika, tetapi juga meliputi berbagai aspek kejahatan yang serius, seperti korupsi, pengelakan pajak, perjudian, penyelundupan dan lain-lain. Sedangkan dari segi politik akan sangat berdampak terhadap segi-segi fundamental negara yaitu rule of law dan pe-merintahan yang demokratis.

2. Upaya Indonesia dalam mengantisipasi pratik pencucian uang.

Indonesia lebih mengenal mengenai "pencucian uang" sejak dimasukkannya Indonesia untuk pertama kali dalam Non-Cooprative Countries and Territories (NCCT) pada tahun 2001 oleh FATF, bersama 14 negara lainnya, yang pada akhirnya mendorong otoritas moneter dan hukum di Indonesia untuk segera bereaksi positif. Adapun upaya Indonesia agar dapat dikeluarkan dari daftar hitam tersebut dapat dibedakan kedalam dua macam tindakan yaitu:

a. Inisiatif dari dari Bank Indonesia mengeluarkan "prinsip mengenal nasabah" (Know Your Customer) melalui Peraturan Bank Indonesia.

Sejalan dengan rekomendasi FATF yang menyatakan bahwa setiap negara harus memiliki rezim hukum anti pencucian uang, 
Basle Commitee on Banking Supervision juga merekomendasikan agar supaya sistem perbankan tidak dipergunakan sebagai sarana tindak pidana atau sarana money laundering. Oleh karena itu sebaiknya bank harus menerapkan prinsip Know Your Customer dengan baik disertai dengan sistem pe-laporan yang memadai. ${ }^{11}$

Atas dasar kondisi kritis pada saat itu dengan adanya desakan dari FATF untuk segera membuat undang-undang tindak pidana pencucian uang, sedangkan pembuatan undang-undang tersebut cukup lama belum jadi, maka Bank Indonesia (otoritas moneter) melalui Peraturan Bank Indonesia mengeluarkan ketentuan "prinsip mengenal nasabah" (Know Your Customer) sebagai upaya untuk men-cegah digunakan bank sebagai sarana dan sasaran tindak pidana pencucian uang. Kebijakan Bank Indonesia dalam me-netapkan "prinsip mengenal nasabah" (Know Your Customer) tertuang dalam Peraturan Bank Indonesia No.3/10/ PBI/2001 tentang Penerapan Prinsip Mengenal Nasabah (Knowing Your Customer Principle) beserta perubahannya yaitu Peraturan Bank Indonesia No. 3/23/PBI/ 2001, (selanjutnya disebut PBI KYC).

Berdasarkan PBI KYC, bank wajib menerapkan prinsip mengenal nasabah. Dijelaskan Sundari S. Arie M bahwa yang dimaksud dengan prinsip KYC adalah prinsip yang diterapkan bank unruk mengetahui identitas nasabah, memantau kegiatan transaksi nasabah termasuk palaporan transaksi yang mencurigakan. Disamping untuk mengendalikan risiko, penerapan prinsip ini dimaksudkan untuk mencegah dipergunakannya bank sebagai sarana atau sarana tindak pidana pencucian uang oleh nasabah bank. ${ }^{12}$

Dalam menerapkan Prinsip Mengenal Nasabah dimaksud bank wajib :

11 Rubrik, "Lokakarya Terbatas Tentang UU No. 15 Tahun 2002 tantang Tindak Pidana Pencucian Uang," Newsletter, No. 51/Desember/2002. hlm. 27

12 Sundari S. Arie M dalam rubrik "Lokakarya Terbatas Tentang UU No. 15 Tahun 2002 tentang Tindak Pidana Pencucian Uang," Newsletter No. 51/Desember/2002. $\mathrm{hlm} .28$
1) Menetapkan kebijakan penerimaan nasabah;

2) Menetapkan kebijakan dan prosedur identifikasi nasabah;

3) Menetapkan kebijakan dan prosedur pemantauan terhadap rekening dan transaksi nasabah;

4) Menetapkan kebijakan dan prosedur manajemen riiko yang berkaitan dengan penerapan KYC;

5) Membentuk unit kerja khusus dan atau pejabat yang bertanggung jawab atas pelaksanaan KYC yang bertanggung jawab kepada Direktur Kepatuhan;

6) Melaporkan transaksi yang mencurigakan (suspicious transaction) ke Bank Indonesia selambat-lambatnya 7 hari kerja setelah diketahui oleh Bank;

7) Menerapkan prinsip KYC yang berlaku di suatu negara bagi kantor cabang bank yang berada di luar negeri, sepanjang standar KYC nya sama atau lebih ketat dari yang diatur dalam PBI, jika ketentuan setempat lebih longgar wajib diterapkan PBI KYC. Dalam hal penerapan $\mathrm{PBI}$ KYC mengakibatkan pelanggaran ketentuan negara setempat wajib dilaporkan ke kantor pusatnya dan Bank Indonesia.

Identitas calon nasabah harus dapat dibuktikan dengan keberadaan dokumendokumen pendukung dan bank wajib meneliti kebenaran dokumen pendukung identitas calon nasabah. Bagi bank yang telah menggunakan media elektronis dalam pelayanan jasa perbankan (misalnya fasilitas ATM, internet banking, dan (ain-lain), wajib melakukan pertemuan dengan calon nasabah sekurang-kurangnya pada saat pembukaan rekening.

Dalam hal calon nasabah bertindak sebagai perantara dan atau kuasa pihak lain (beneficial owner) untuk membuka rekening, bank wajib memperoleh dokumen pendukung identitas, hubungan hukum, penugasan, serta kewenangan bertindak sebagai perantara dan atau kuasa pihak lain. Selama bertahun-tahun FATF sangat peduli 
terhadap tersedianya informasi tentang orang/korporasi yang merupakan pemilik rekening yang sebenarnya (beneficial owner) yang mengawasi harta kekayaannya (termasuk dana di bank) yang berasal dari kejahatan. Orang/korporasi tersebut pada umumnya meningkatkan penggunaan berbagai macam jenis badan hukum atau caracara untuk menyembunyikan kekayaannya yang merupakan bagian dari proses pencucian uang.

Ketentuan dalam PBI No. 3/10/PBI/ 2001 tersebut diatas tidak berlaku bagi nasabah yang tidak mempunyai rekening di bank (walk-in customers), sepanjang nilai transaksinya tidak melebihi Rp.100 juta, sehingga nasabah yang tidak memiliki rekening bank tetap dapat menggunakan jasa perbankan dengan nilai transaksi tidak melebihi Rp.100 juta. Dengan demikian sesuai PBI KYC bank harus menerapkan prosedur untuk mendentifikasi nasabah kepada seluruh walk-in customers yang transaksinya melebihi Rp.100 juta.

Selanjutnya pada bulan Desember 2001 Bank Indonesia menetapkan PBI No. 3/23/PBI/2001 tentang Perubahan atas Penerapan Prinsip Mengenal Nasabah (Knowing Your Customer Policy) beserta Pedoman Standar KYC. Beberapa perubahan penting yang ditetapkan dalam ketentuan tersebut adalah sebagai berikut:

1) Kebijakan dan prosedur KYC :

a) Bank wajib membuat Pedoman Pelaksanaan Penerapan Prinsip Mengenal Nasabah yang wajib disampaikan oleh bank kepada Bank Indonesia selambatlambatnya pada tanggal 13 Februari 2001;

b) Penyusunan pedoman tersebut di atas wajib mengacu pada pedoman satndar yang telah ditetapkan oleh Bank Indonesia sebagaimana ditetapkan dalam SE BI No. 3/29/DPNP tanggal 13 Desember 2001;

c) Setiap perubahan pedoman tersebut wajib dilaporkan kepada Bank Indo- nesia selambat-lambatnya 7 hari kerja sejak ditetapkan;

d) Bank wajib menerapkan KYC terhadap nasabah baru sesuai Pedoman Palaksanaan Penerapan Prinsip Mengenal Nasabah.

2) Bank wajib menerapkan prinsip KYC dan melakukan pengkinian data base nasabah yang sudah ada (existing customer) selambat-lambatnya tanggal 13 Juni 2001;

3) Bank wajib melaksanakan program pelatihan kepada karyawan bank mengenai prinsip KYC selambat-lambatnya tanggal 13 Februari 2001;

4) Penerapan sistem informasi yang dapat mengidentifikasi, menganalisa, memantau dan menyediakan laporan secara efektif mengenai karakteristik transaksi yang dilakukan oleh nasabah bank sudah harus siap selambat-lambatnya tanggal 13 Juni 2001.

Untuk itu bank wajib memiliki sistem informasi yang dapat mengidentifikasi, menganalisa, memantau dan menyediakan laporan secara efektif mengenai karakteristik transaksi nasabah serta wajib memelihara profil nasabah (baik yang baru maupun existing customer) yang sekurangkurangnya meliputi informasi tentang pekerjaan atau bidang usaha, jumlah penghasilan, rekening lain yang dimiliki, aktivitas transaksi normal dan tujuan pembukaan rekening.

b. Tindakan pemerintah mengeluarkan undang-undang pemberantasan tindak pidana pen-cucian uang

Pada tanggal 17 April 2002, pemerintah mengeluarkan UU No. 15 Tahun 2002 tentang Tindak Pidana Pencucian Uang (selanjutnya disebut UUTPU). Adapun pokokpokok yang diatur dalam UUTPU tersebut adalah :

1) Pengaturan cara perbuatan pencucian uang.

2) Pengertian kegiatan pencucian uang dan tindak pidana yang merupakan sumber pencucian uang (predicate crimen/offence) yaitu tindak pidana korupsi; pe- 
nyuapan; penyelundupan barang; penyelundupan tenaga kerja; penyelundupan imigran; perbankan; nakotika; psikotropika; perdagangan budak, wanita dan anak; perdagangan senjata gelap; penculikan; terorisme; pencurian; penggelapan; penipuan.

3) Pelaku tindak pidana pencucian uang dapat dikenakan sanksi pidana paling sedikit 5 (lima ) tahun dan paling lama 15 (lima belas) tahun penjara dan denda paling sedikit Rp. 5.000.000.000,00 (lima milyar rupiah) dan paling banyak Rp. 15.000 . 000.000,00 (lima belas milyar rupiah).

4) Lembaga Keuangan wajib melaporkan transaksi keuangan yang mencurigakan dan transaksi keuangan yang dilakukan secara tunai dalam jumlah kumulatif sebesar Rp. 500.000,00 (lima ratus ribu rupiah) atau lebih atau yang nilainya setara, baik dilakukan dalam satu kali transaksi maupun beberapa kali transaksi dalam satu hari kerja.

5) Pembentukan Komisi Pemberantasan Tindak Pidana Pencucian Uang (KPTPPU).

6) Kewajiban nasabah deposan (perorangan maupun koperasi) untuk menyampaikan identitas secara lengkap dan benar termasuk untuk nasabah bank, reksa dana dan perusahaan efek.

7) Perlindungan hukum bagi pelapor dan saksi.

Dalam rangka menangani masalah pencucian uang, didirikan Pusat Pelaporan dan Analisis Transaksi Keuangan (PPATK) sebagai lembaga permanen yang khusus menangani masalah pencucian uang. Lembaga ini merupakan salah satu infra struktur terpenting dalam upaya pencegahan dan pemberantasan kejahatan pencucian uang. Tugas PPATK antara lain: mengumpulkan, menyimpan, menghimpun menganalisis mengevaluasi informasi yang diperoleh berdasarkan UU ini dan menyebarluaskan, membuat pelaporan transaksi keuangan yang mencurigakan, memberikan nasihat dan bantuan kepada instansi lain yang berwenang mengenai informasi yang diperoleh sesuai ketentuan
UU, memberikan rekomendasi kepada pemerintah sehubungan dengan pencegahan dan pemberantasan tindak pidana pencucian uang, melaporkan hasil analisis terhadap transaksi keuangan yang berindikasi tindak pidana pencucian uang kepada Kepolisisan untuk kepentingan penyidikan dan Kejaksaan untuk kepentingan penuntutan dan pengawasan, membuat dan menyampaikan laporan mengenai analisis transaksi keuangan dan kegiatan lainnya secara berkala kepada Presiden DPR dan lembaga yang berwenang melakukan pengawasan bagi Penyedia Jasa Keuangan (PJK).

Permasalahan penaggulangan pencucian uang bukanlah masalah sederhana dan mudah, bahkan bagi internasional termasuk berbagai negara yang sudah maju. Pada milenium ini, fenomena memerangi pencucian uang memperlihatkan peningkatan yang signifikan baik dalam skala internasional oleh berbagai negara, maupun dalam tingkat domestik. Upaya keras internasional tersebut tidak hanya menekankan pada pembuatan peraturan perundang-undangan yang diarahkan untuk memerangi organized crimes terutama organized drug trafficking tetapi juga berbagai kejahatan lain.

Upaya yang dilakukan untuk pencegahan dan penanggulangan pencucian uang secara gradual melibatkan dua kebijakan hukum yaitu dengan pendekatan preventif melalui hukum perbankan dan secara represif melalui hukum pidana. Namun keduanya tidak dapat dipisahkan secara dikhotomis tetapi saling berkaitan sehingga disebut sebagai ssistem dua jalur (twins track against money laundering).

Di Indonesia penggunaan pendekatan preventif dilakukan melalui peningkatan kewaspadaan lembaga keuangan melalui Prinsip Mengenal Nasabah (Knowing Your Customer Principle) beserta perubahannya yaitu Peraturan Bank Indonesia No. 3/23/PBI/2001; Sedangkan secara represif melalui sistem peradilan pidana yang dimulai dengan langkah kriminalisasi melalui UU No. 15 Tahun 2002 tentang Tindak Pidana Pencucian Uang (UUTPU). 
244 Jurnal Dinamika Hukum

Vol. 9 No. 3 September 2009

Walaupun UUTPPU telah dimiliki namun oleh FATF Indonesia tetap dianggap sebagai negara yang tidak kooperatif dalam menanggulangi pencucian uang dan masih terancam sanksi keras karena UUTPPU dipandang lemah dan tidak mengikuti standar internasional. Beberapa kelemahan yang terkandung dalam UUTPPU yang oleh FATF perlu dilakukan perubahan adalah (8 rekomendasi khusus) :

1) Batasan jumlah yang ditetapkan senilai Rp. 500.000.000,00 dinilai tidak efektif dan dianjurkan untuk dihapuskan.

2) UUTPPU tidak memassukkan tipping off, larangan bagi penyedia jasa untuk memberitahukan kepada nasabahnya tentang laporan transaksi keuangan mencurigakan yang terkait dengan nasabaha tersebut.

3) UUTPPU masih mendefinisikan secara sempit tentang trnasaksi keuangan mencurigakan, dimana dalam definisi tersebut tidak mencakup transaksi keuangan maupun percobaan transaksi keuangan dengan menggunakan dana yang diduga dari hasil tindak pidana.

4) Jangka waktu laporan keuangan yang ditetapkan dalam UUTPPU terlalu lama, yaitu 14 hari, sehingga diduga akan menyulitkan pemberantasan tindak pidana pencucian uang.

5) Terbatasnya jumlah predicate offense dan tidak dimassukkannya perjudian ke dalam daftar predicate offense.

6) Kerjasama internasional belum diatur secara rinci.

Sebagai jawaban dari adanya desakan FATF mengenai komitmen Indonesia dalam masalah pencucian tersebut UUTPPU kemudian diamandemen dengan UU No. 25 Tahun 2003 tentang Perubahan atas Undang-undang No. 15 Tahun 2002. Dalam perubahan ini, keempat kelemahan tersebut dirubah/direvisi seperti ketentuan mengenai batasan Rp. 500.000.000 dihapuskan, kemudian penambahan Pasal $17 \mathrm{~A}$ mengenai Anti-Tipping off dan perluasan definisi mengenai transaksi keuangan yang mencurigakan, serta perubahan jangka waktu kewajiban penyampaian laporan transaksi keuangan mencurigakan oleh penyedia jasa keuangan dari 14 hari menjadi 3 hari. Selain itu mengenai jenis tindak pidana yang menjadi dasar pencucian uang mengalami penambahan menjadi 25 jenis tindak pidana.

Akan tetapi setelah dilakukan amandemen, ternyata FATF masih meragukan dari sudut implementasinya, sehingga Indonsia masih masuk daftar hitam bersama 11 negara lainnya. Kali ini alasannya Indonesia masih belum memperlihatkan kesungguhan dan diminta untuk memberikan draft implementasi yang akan dinilai kembali oleh FATF pada Februari 2004. Pada pertemuan antara Indonesia dengan FATF di Seoul (14 - 18 Juni 2004) yang kemudian hasil pembahasan itu dibawa ke sidang FATF di Paris (2-4 Juli) ternyata akhirnya FATF tetap bersikukuh masih memasukkan Indonesia dalam daftar hitam bersama 6 negara lainnya (Philipina, Nauru, Cook Island, Nigeria dan Myanmar).

Belum percayanya FATF atas kesungguhan Indonesia dalam pemberantasan tindak pidana pencucian uang, terutama adalah mereka belum melihat satupun kasus pencucian uang sampai ke pengadilan.

Mengenai implementasi UUTPPU menimbulkan masalah bagi Indonesia dalam menegakkan hukum anti pencucian uang, setidaknya menuntut para pelaku yang diduga melakukan pencucin uang ke pengadilan? Ternyata para penegak hukum - dalam hal ini Kepolisian dan Kejaksaan - masih menggunakan peraturanperaturan hukum yang ditujukan untuk menjerat predicate offense seperti Undang-undang Anti Korupsi. Sebagai bentuk penaggulangan dan pemberantasan kejahatan, hal itu dapat dibenarkan, akan tetapi sebagai suatu implementasi anti pencucian uang, hal tersebut tidak dibenarkan. Sebab yang FATF inginkan adalah penuntutan kasus-kasus seperti kasus BNI dilakukan dengan menggunakan UUTPPU sebagai unang-undang anti penccucian uang, bukan dengan UU Anti Korupsi atau peraturan lainnya, karena dalam kasus BNI ini disinyalir telah terjadi tindak pidana pencucian uang melalui placement dan layering atas uang hasil kejahatan tersebut. Selain itu FATF juga menginginkan pelaku-pelaku dalam kasus BNI 
tersebut diberikan hukuman berdasarkan Undang-undang Anti Pencucian yaitu UUTPPU.

Sebagai perbandingan, Ukrania telah memutus 47 kasus pencucian uang sejak efektif bekerja melakukan pemberantasan termasuk menghukum mati seseorang yang dekat dengan Perdana Menteri karena terbeukti melakukan pencucian uang. Kerja pemberantasan yang efektif inilah yang menyebabkan Ukrania dalam sidang FATF keluar dari daftar hitam negara yang tidak kooperatif dalam memberantas pencucian uang, kemudian dalam enam bulan pertama tahun itu Ukrania telah menemukan 224.000 transaksi keuangan mencurigakan.

Menurut Eddie Trinugroho, di Indonesia transaksi keuangan yang diterima PPATK hanya 714 laporan, dan dari 714 laporan tersebut 295 transaksi 119 diteruskan ke tingkat penyidikan dengan rincian 53 kasus adalah tindak penipuan, 16 kasus korupsi, 5 kasus terorisme, 4 kasus pemalsuan dokumen dan 12 kassus tidak teridentifikasi. $^{13}$

Selama belum ada penyelesaian kasus pencucian uang dan implementasi nyata dari UUTPPU, maka Indonesia dipastikan masih termasuk dalam daftar hitam NCCT FATF.

\section{Penutup}

\section{Simpulan}

Apa yang bisa ditarik dari pembahasan tersebut diatas dapatlah diambil kesimpul-an sebagai berikut :

a. Dalam sejarahnya pencucian uang terjadi apabila seseorang telah melakukan kejahatan dan kemudian dia melakukan perbuatan lain untuk menyembunyikan hasil kejahatan itu. Pada dasarnya proses pencucian uang terdiri dari tiga langkah yang masing-masing berdiri sendiri, tetapi seringkali dilakukan bersama-sama yaitu : 1). menempatkan uang hasil kejahatan dalam sistem keuangan melalui penyedia jasa keuangan (placement), kemudian 2). mentransfernya ke penyedia jasa ke-uangan lainnya dengan menggunakan berbagai rekening atas nama nasabah yang tidak saling mengenal satu sama lain, antar bank serta antar negara untuk menyamarkan asal usul dana tersebut (layering); dan selanjutnya 3). menggunakan uang hasil kejahatan dalam kegiatan resmi sesuai dengan aturan hukum sehingga tampak tidak berhubungan sama sekali dengan aktivitas kejahatan sebelumnya yang menjadi sumber dari uang yang dicuci (inte-ration). Dengan demikian kejahatan pencucian uang sebenarnya mengandung dua bentuk kejahatan (dual crime act), yaitu tindak pidana awal (predicate crime/offense) dan tindak pidana pencucian uang.

b. Upaya Indonesia dalam memerangi prak-tik pencucian uang secara gradual dilakukan melalui dua jalur kebijakan hukum yaitu :

1) Kebijakan Hukum Perbankan sebagai pendekatan preventif berupa penetapan Prinsip Mengenal Nasabah (Knowing Your Customer Principle).

2) Kebijakan Hukum pidana sebagai pendekatan represif berupa kriminalisasi tindakan pencucian uang sebagaimana diatur dalam UU No. 15 Tahun 2002 dan perubahannya UU No. 25 Tahun 2003.

Namun demikian dalam implementasinya FATF masih meragukan kesungguhan Indonesia dalam pemberantasan tindak pidana pencucian uang, karena sejak diundangkan sampai sekarang belum satupun kasus pencucian uang sampai ke pengadilan.

\section{Rekomendasi}

Agar Indonesia dianggap kooperatif dan dikeluarkan dari daftar hitam Non-Cooperative Countries and Territories (NCCT) oleh Financial Action Task Force (FATF), maka sebaiknya aparat penegak hukum, dalam hal ini Kepolisian dan Kejaksaan, tidak lagi menggunakan peraturan-peraturan hukum uang menjerat predicate offense, melainkan menggunakan undang-undang anti pencucian uang (UUTPPU), se-bagai bentuk penanggulangan dan pemberantasan kejahatan pencucian uang.

13 Eddie Trinugroho, Ibid, $h \mathrm{~lm} .7$. 
246 Jurnal Dinamika Hukum

Vol. 9 No. 3 September 2009

\section{Daftar Pustaka}

Garnasih, Yenti. Pencucian Uang dan Permasalahan Penegakannya di Indonesia. Newsletter No. 58/September/2004;

Gislir, Muhammad Aulia. Aspek Hukum Praktek Money Laundering Melalui Sarana Perbankan. Newsletter No. 39/X/Desember/1999;

Husein, Yunus. Keberadaan Undang-undang Money Laundering. Newsletter No. 48/ Maret/2002;

M., Sundari S. Arie. Lokakarya Terbatas Tentang UU No. 15 Tahun 2002 tentang Tindak Pidana Pencucian Uang. Newsletter No. 51/ Desember /2002;

Trinugroho, Eddhie. Perkembangan Pemberantasan Tindak Pidana Pencucian Uang di Indonesia. Newsletter No. 58/September 2004.
Peraturan Perundang-undangan :

Undang-undang No. 15 Tahun 2002 tentang Tidak Pidana Pencucian Uang

Undang-undang No. 25 Tahun 2003 tentang Perubahan Atas Undang-undang No. 15 Tahun 2002 tentang Tidak Pidana Pencucian Uang.

Peraturan Bank Indonesia No. 3/10/PBI/2001 tentang Penerapan Prinsip Mengenal Nasabah (Know Your Customer.

Peraturan Bank Indonesia No. 3/23/PBI/2001 tentang Perubahan Peraturan Bank Indonesia No. 3/10/PBI/2001 tentang Penerapan Prinsip Mengenal Nasabah (Know Your Customer).

Peraturan Bank Indonesia No. 3/10/PBI/2001 tentang Penerapan Prinsip Mengenal Nasabah (Know Your Customer). 